\title{
THE ARIES DIAMONDIFEROUS KIMBERLTE PIPE, CENTRAL KIMBERLEY BLOCK, WESTERN AUSTRALIA: MINERALOGY, PETROLOGY AND GEOCHEMISTRY OF THE PIPE ROCK AND INDICATOR MINERALS̀.
}

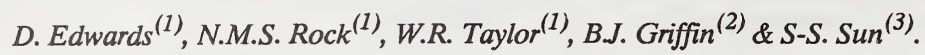 \\ (1)Geology Dept., University of Western Australia, Nedlands 6009, WA; (2)Electron Microscopy Centre, University of \\ Western Australia, WA; (3)Bureau of Mineral Resources, Canberra 2601, ACT.
}

The mineralogy of the Aries pipe is very similar to that of S.African Group II (micaceous) kimberlites, but differs from that of typical lamproites, not least in the abundance of carbonate and absence of diagnostic lamproitic minerals such as priderite and richterite (Table 1). Three textural varieties of Aries magmatic kimberlite can be recognized in pipe rock from available drillcore: (1) macrocrystal medium-grained; (2) aphanitic ( $\leq 5$ vol\% olivine macrocrysts); and (3) macrocrystal segregated. Autoclastic breccias are also abundant. The kimberlites contain two generations of olivine pseudomorphs (3040 vol\%), and two of phlogopite (up to $60 \mathrm{vol} \%$ ), in a groundmass of apatite, calcite, diopside, sphene, spinels, serpentine, talc, and accessory groundmass minerals such as aeschynite $\left[(\mathrm{Ce}, \mathrm{Ca})(\mathrm{Ti}, \mathrm{Nb}){ }_{2} \mathrm{O}_{6}\right]$, barite, ilmenite, monazite, rutile, siderite, and unidentified $\mathrm{Nb}-\mathrm{Fe}$-titanates.

Phlogopite is complexly zoned, with somewhat distinct compositional trends among the pipe's, four lobes, but follows kimberlitic compositions and trends on $\mathrm{Al}-\mathrm{Ti}$ plots $\left(\mathrm{TiO}_{2}\right.$ 0.5-4 wt. $\frac{\circ}{\circ} \mathrm{Al}_{2} \mathrm{O}_{3}$ 9-16wt\%); $\mathrm{Cr}_{2} \mathrm{O}_{3}$ and $\mathrm{BaO}$ both range up to $1.5 \mathrm{wt} \%$ and $\mathrm{F}$ up to 1.8wt\%; local tetraferriphlogopite substitution is indicated. Diopside is low in $\mathrm{Cr}, \mathrm{Al}, \mathrm{Na}$ and $\mathrm{Ti}$ with high $\mathrm{Mg \#}$ $\left(\mathrm{Mg} /\left[\mathrm{Mg}+\mathrm{Fe}^{2}\right] \approx 93\right)$. Apatite contains variable SrO (up to $17.5 \mathrm{wt} \%)$. Sphene contains significant $\mathrm{Nb}_{2} \mathrm{O}_{5}(\leq 1.5 \mathrm{wt} \%)$ and $\mathrm{FeO}$ $(\leq 2 \mathrm{wt} \%)$. Rare ilmenite contains $2.6 \mathrm{wt} \div \mathrm{Nb}_{2} \mathrm{O}_{5}$ and $16 \mathrm{wt} \% \mathrm{MnO}$ but no detectable MgO. Calcite is virtually Mg-Fe-free but has up to $1.7 \mathrm{wt} \%$ SrO and $0.5 \mathrm{wt} \% \mathrm{MnO}$.

\section{TABLE 1}

Mineralogical summary comparison of Aries rocks with lamproites, Group I and Group II kimberlites

\begin{tabular}{|c|c|c|c|c|c|c|c|c|c|c|}
\hline & Olivine & $\overline{C p x}$ & Calcite & $\begin{array}{c}\text { Amphi } \\
\text {-bole }\end{array}$ & $\begin{array}{c}\text { Phlogo- } \\
\text { pite }\end{array}$ & $\begin{array}{l}\text { Monti- } \\
\text { cellite }\end{array}$ & $\begin{array}{l}\text { Leucite, } \\
\text { sanidine }\end{array}$ & Ilmenite & $\begin{array}{l}\text { Priderite } \\
\text { etc. }\end{array}$ & $\begin{array}{l}\text { Zircon, } \\
\text { perovsk. }\end{array}$ \\
\hline $\begin{array}{l}\text { Olivine- } \\
\text { lamproite }\end{array}$ & abundant & common & rare & minor & abundant & absent & minor & rare & present & present \\
\hline $\begin{array}{l}\text { Leucite- } \\
\text { lamproite }\end{array}$ & minor & common & rare & present & abundant & absent & present & present & common & absent \\
\hline $\begin{array}{l}\text { Group I } \\
\quad \text { kimberlite }\end{array}$ & dominant & absent & abundant & absent & minor & common & absent & common & absent & present \\
\hline $\begin{array}{l}\text { Group II } \\
\quad \text { kimberlite }\end{array}$ & dominant & common & abundant & v.rare & abundant & absent & absent & rare & absent & absent \\
\hline Aries & dominant & present & abundant & absent & abundant & absent & absent & v.rare & absent & absent \\
\hline
\end{tabular}

common = commonly present but only in small amounts

present $=$ commonly present but in variable amounts

Data summarized from Jaques et al.(1986), Mitchell (1986), Skinner (1989) and Mitchell \& Bergman (1991) 
Complex morphological, textural and compositional variations are present in drillcore spinels. They can be divided into five main textural-genetic types: (1) cognate groundmass chrome spinels;

(2) chrome spinels included in olivine macrocrysts, probably representing either early phenocrysts or mantle xenocrysts; macrocryst chrome spinels, probably representing xenocrysts; late-stage groundmass ferric spinels, probably derived from serpentinization of olivine; (5) alteration ferric spinels, found as inclusions associated with siliceous melt inclusions in other spinels, and probably representing interaction of types (2) and (3) with late-stage melts. Some of these show further textural sub-types with no recognized genetic significance.

The Aries pipe is rich in country-rock (basalt, quartzite) xenoliths, but the only mantle-type materials so far yielded have been two diamond indicator minerals - spinel and rare garnet - recovered as isolated grains via heavy-mineral concentrate (HMC) programmes. Aries HMC chrome spinels can be easily distinguished, texturally and compositionally, from basaltic spinels derived from the local country-rocks. Like chrome spinels from the drillcore, they show complex textural, morphological and compositional variations, but six distinct textural types can be combined into two broader texturalcompositional classes. Class 1 spinels show replacement textures, are non-stoichiometric, Cr-rich (up to 67wt\%), apparently free of $\mathrm{Fe}^{3+}$, and may carry $\mathrm{Cr}^{2+}$; they probably originated from metasomatised, depleted harzburgitic mantle within the diamond stability field at the base of the lithosphere. Central and South Lobes have abundant Class 1 spinels but North Lobe and North Extension virtually lack them. All four lobes contain texturally diverse class 2 spinels, which show 'fractured, interlocking, pockmarked, symplectic or uniform' textures; these are more oxidized, poorer in $\mathrm{Cr}_{2} \mathrm{O}_{3}$, and higher in MgO than Class 1, and may have originated from shallower mantle sources.

Garnets are relatively rare in Aries heavy-mineral concentrates and have not been identified at all in drillcore. The few analyzed to date are ' $G 9$ ' and ' $G 11$ ' compositions under Dawson \& Stephens' classification (55-60mol\% pyrope, 7-10wt\% $\mathrm{CaO}, 8-11$ wt $\mathrm{Cr}_{2} \mathrm{O}_{3}, 16-18 \% \mathrm{MgO}$ ), indicating lherzolitic and/or wehrlitic sources on the Sobolev et al. scheme. Despite the known diamond potential of the pipe, none of the 'G10'

(subcalcic chrome pyrope) garnets regarded in southern Africa as a hallmark of diamondiferous pipes have yet been identified. This is however consistent with data from other Australian pipes, suggesting 'GlO' garnets to be a less reliable diamond indicator in Australia than in southern Africa.

Several magma-pulses were involved in the formation of the Aries pipe. All four lobes probably contain at least one magmapulse in common; this sampled one class of HMC spinels and is characterized by similar phlogopite zoning trends. However, Central and South Lobes contain magma(s) which sampled another 
whilst North Lobe and North Extension contain magma(s) which may have been generated at higher levels in the mantle, yielded comparatively evolved phlogopite trends, and probably reduced their diamond prospectivity relative to the other lobes.

Geochemically Aries is again most like S.African Group II kimberlites. Certain incompatible element abundances and ratios (e.g. very high $\mathrm{Nb} / \mathrm{Zr}$ ) are unusual, but are shared with at least two other contemporaneous $(\approx 820 \mathrm{Ma})$ lamprophyric intrusions of the east Kimberley (at Maude Creek and Bow Hill), suggesting a regionally anomalous mantle source (Fig.1). Isotopically, however, Aries had $\varepsilon_{\mathrm{Nd}} \approx-1$ when it was emplaced, $\approx 820 \mathrm{Ma}$ ago $(\approx$ -14 present-day $\left.\varepsilon_{\mathrm{Nd}}\right)$; this tends to suggest that unlike Argyle, the W.Kimberley lamproites, or Group II kimberlites of S.Africa, any contribution to Aries from an ancient, LREE-enriched lithospheric component is minor.

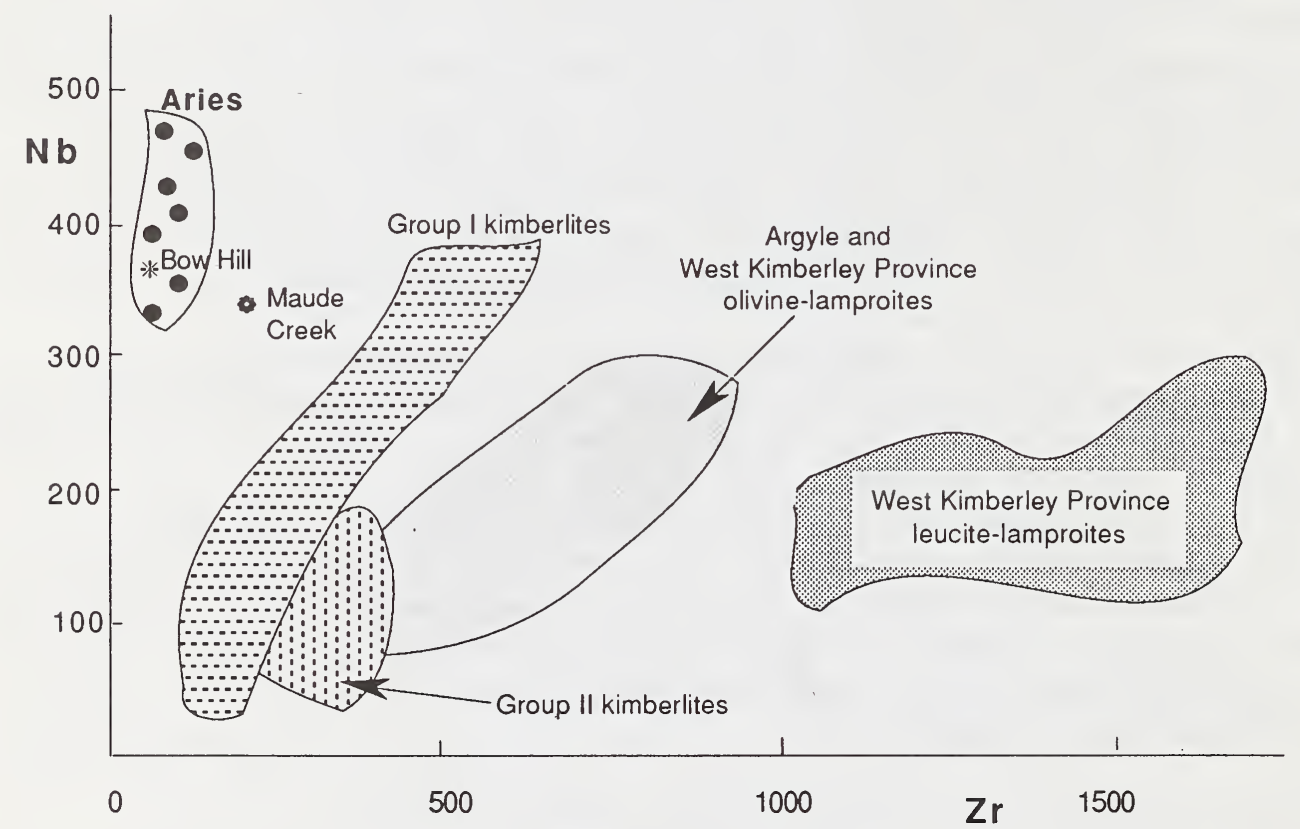

FIG.1. Nb versus $\mathrm{Zr}$ plot (ppm). Aries whole-rocks are compared with west Australian lamproites and the two global groups of kimberlites

The regional distribution of Aries and other lamprophyric bodies in and around the Australian Kimberley craton has two implications.(1) There exists a scattered magmatic province in the Kimberley, resulting from an $\approx 800$ Ma lamprophyric intrusive event; as well as Aries in the central Kimberley, this includes all dated bodies from the currently named North Kimberley Province (e.g. Skerring kimberlite), and some from the East Kimberley 'province' (Bow Hill lamprophyres, but not the Argyle lamproite). (2) The traditional s.African model of diamond occurrence (Clifford's rule) requires modification if it is to be applied in the Australian Kimberley. 